\author{
M. L. Gargano, G. De Mastro, F. S. D’Amico, F. Cirlincione, E. Di Gristina \\ \& G. Barone
}

\title{
Acclimatization, distribution and potential economic use of Argania spinosa (Sapotaceae) in southern Italy
}

\begin{abstract}
Gargano, M. L., De Mastro, G., D’Amico, F. S., Di Gristina, E. \& Barone, G.: Acclimatization, distribution and potential economic use of Argania spinosa (Sapotaceae) in southern Italy. Fl. Medit. 31: 173-181. 2021. — ISSN: 1120-4052 printed, 2240-4538 online.

The authors report updated notes on the acclimatization, distribution, areas suitable for cultivation and, potential use of Argania spinosa (Sapotaceae) in southern Italy. Based on observations carried out on the plants cultivated in Bari and the Botanical Garden of Palermo, and on ecological requirements of the species it is possible to consider A. spinosa as a woody species easily adaptable to the coastal climate of southern Italy.
\end{abstract}

Key words: Argania, medicinal plant, zoning model.

\section{Introduction}

Argania spinosa Skeels (syn. Argania syderoxylon L., Sideroxylon spinosum L.), the argan tree, belongs to the Sapotaceae family and it is the only species of its genus (Khallouki \& al. 2005; Zunzunegui \& al. 2010; Ait Aabd \& al. 2019).

As a plant of particular botanical interest, ecological services, and socioeconomic value, it has been investigated at different levels. The structural organization and phylogenetic relationships in Sapotaceae was clarified by Khayi \& al. (2020). Chakhchar \& al. (2020) highlighted morphological aspects and physiological and biochemical mechanisms related to the roots to justify the tolerance of $A$. spinosa to abiotic stresses.

The adaptation to aridity of $A$. spinosa has been pointed out by Tahrouch $\&$ al. (2011) analyzing the leaves, stems and thorns which show a high concentration of myricetin. An ethobotanical investigation was carried out by Moukal (2004) in the rural areas of SouthWest Morocco on the several uses of the argan tree as therapeutic and cosmetic. Guillaume \& al. (2019) highlighted the antioxidant and pharmacological properties of argan oil and the value of by-products derived from it. 


\section{Description}

A. spinosa is a slow growing spiny tree with a maximum height of ca. $10 \mathrm{~m}$ (Charrouf $\&$ Guillaume 1999), able to live up to an age of about 200 years. (Khallouki \& al. 2005). The leaves are small $(20 \mathrm{~mm})$, with entire margin and spatulate shape. Although the plant is evergreen, the leaves may fall off, totally or partially, especially in response to summer stress. So it is preferable to consider this species as a facultative summer semi-deciduous (M'Hirit \& al. 1998).

Flowering occurs mainly in spring, with great variation among individuals, and with a secondary peak in autumn. Fruits are olive-like, stalkless drupes with a hard endocarp protecting an oil rich kernel (Zunzunegui \& al. 2010). Therefore, fruit production extends over a long period and fruits can be found in different ripening phases from April to September (M’Hirit \& al. 1998).

\section{Ecology and distribution}

A. spinosa is endemic to the arid and semiarid areas of South-western Morocco, mostly in the Souss Valley, between Safi and Goulimime (Msanda \& al. 2021), where it occupies more than $8.000 \mathrm{~km}^{2}$ on a wide range of altitude, from sea level to $1.500 \mathrm{~m}$ (Justamante \& al. 2017). Other populations are found in Algeria in the Tindouf region (Khallouki \& al. 2017; Kechairi \& Benmahioul 2019). The range is in the transitional area between the Mediterranean iso-climatic zone in the north and the Saharan region in the south and has a wide opening to the Atlantic Ocean (Msanda \& al. 2021). This species is cultivated and subspontaneous in the Canary Islands (WCSP 2021), continental Spain (Castroviejo 1997), and Libya (APD 2021).

A. spinosa is the second most common tree in Morocco, preceded only by Quercus ilex L. (Khallouki \& al. 2005). The argan tree is adapted to grow in a harsh environment, surviving extreme drought and poor soil. The optimal rainfall pattern for the species is 500 $\mathrm{mm}$ per year; nevertheless, $120 \mathrm{~mm}$ of rain make up the minimum necessary for its development (Raimondo \& al. 2005). It can resist to temperatures below $0{ }^{\circ} \mathrm{C}$ only a short time (Alouani \& Bani-Aameur 2017).

A. spinosa is the only species of the tropical Sapotaceae family, whose range extends to the subtropical zone (Charrouf \& Guillaume 2002). It could be a relict of the Tertiary flora and in that period its range could have been wider, also including the northern part of Africa and Southern Europe; after, the Quaternary glaciations contracted its range. This hypothesis would justify the current existence of the small relict populations distributed in the area of Rabat and even further north, near the Mediterranean coast of north-east Morocco (Raimondo \& al. 2005; Ait Aabd \& al. 2019).

In Morocco, A. spinosa has an indispensable ecological function. Its roots grow deep in search of water and thus help retain the soil, preventing erosion and limiting the advance of the desert (Khallouki \& al. 2005). In addition to these important ecological aspects, argan trees also economically support indigenous populations (Morton \& Voss 1987; Mechqoq \& al. 2021). Their large canopy maintains soil fertility by shading domestic cultures that guarantee most of the dietary needs of small scale farmers (Charrouf \& 
Guillaume 2002). Furthermore, the argan leaves constitute a real pasture suspended for dromedaries and goats. Indeed, these last they climb up to the highest branches to graze the leaves that have considerable forage value (Nouaim \& al. 1991).

However, nowadays, the argan woodlands is steadily decreasing in terms of density and surface covered. This is mainly a consequence of the overuse of argan trees, for wood or forage production, by the native dwellers but has also recently been deeply accentuated by several consecutive unprecedented arid years (Charrouf \& Guillaume 1999). Therefore, sustainable management strategies are needed for the conservation of the species and its genetic diversity (Msanda \& al. 2021).

\section{Economic use}

The argan tree also supports more directly the economy of the region (M'Hirit \& al. 1998) since its fruits provide an edible and marketable oil for cooking, cosmetic and, medicinal purposes (Khallouki \& al. 2005).

The oil provides up to $25 \%$ of the dweller daily lipid diet (Collier \& Lemaire 1974) and possesses a lot of dietary interesting properties. Its quality makes it a great product sought after, much more expensive than olive oil in reason also of its limited availability (Yaghmur \& al. 2001).

In the traditional pharmacopoeia the argan oil is used to fight physiological aging and drying of skin, in the treatment of children's pimples, and more particularly in juvenile acne. By its pharmacological properties, argan oil is also included in the composition of creams used in cosmetics (Khallouki \& al. 2005).

Recognizing its ecological value and local economic importance, the argan forest region was declared a UNESCO Biosphere Reserve in 1998 (Msanda \& al. 2021).

\section{Distribution in Italy and acclimatization}

Acclimatization tests for A. spinosa date back to the $17^{\text {th }}$ century in Holland, the $18^{\text {th }}$ century in Germany, the $19^{\text {th }}$ century in France and, the early $20^{\text {th }}$ century in America (Southern California and Illinois). Recently they have also been carried out in Tunisia, Libya, and Israel, Kuwait, and Mexico (Peltier \& al. 1990; Raimondo \& al. 2005; Falasca \& al. 2018).

In Italy, a plant of $A$. spinosa is cultivated in the Botanical Garden of Cagliari (Sardinia), where the plant is cultivated in open field and vegetatively multiplied by layering. The oldest argan tree, at the side of the central tank of the Botanical Garden and producing fruits, died about 15 years ago (G. Bacchetta, in verbis). Since 1998 two plants have also been cultivated in the Botanical Garden of Palermo (Sicily) where they bloom and bear fruit regularly (Raimondo \& al. 2005).

Two plants were introduced and cultivated outdoors, initially in pots. The plants showed a regular and vigorous growth, keeping their leaves all year round, contrary to what happens in nature. Flowering, occurred for the first time in 2003, was followed by fructification 6 years after planting. As part of a census of the trees and shrubs of the city of Bari 
(Apulia, southern Italy) (Gargano \& al. 2021), a vigorous tree of $A$. spinosa was observed inside the University Campus near the Department of Agricultural and Environmental Science (DiSaat) while the other plant is located in the Botanical Garden of Bari (Fig. 1).

This is one of the plants previously pointed out by Campese \& al. (2011) who reported five argan trees in the University Campus, including two of about $3 \mathrm{~m}$ in height in the ground and three others in pots, in the greenhouses of the former Department of Biology and Plant Pathology of the University of Bari. Campese \& al. (2011) also reported other two specimens cultivated in the province of Bari. Argan plants were introduced from Morocco by Prof. Daniele Sisto, plant pathologist at the University of Bari. A plant was given to Prof. Francesco Macchia, at the time director of the Botanical Garden of Bari for acclimatization. Another was planted in the University Campus, near the former Faculty of Agriculture. In about 20 years, the plant has reached the typical size of the species, bears fruit regularly and abundantly and does not present particular pathologies.

\section{Suitable areas for cultivation in Italy}

A preliminary bibliographic search was undertaken to highlight the sites of the wild plant populations of Argania spinosa. The Moroccan populations have been chosen as a reference because the range in Algeria has been enlarged by man and many populations have been artificially reinforced (Kechairi \& Benmahioul 2019). For trees favoured or cultivated by man, sometimes for millennia, it is necessary to develop approaches combining phylogeography and paleoecology at the scale of the distribution area (Médail \& al. 2019). The selected Moroccan populations were mapped on a GIS system. The climatic requirements and tolerances of $A$. spinosa have been outlined in relation to the environmental conditions of its natural distribution range. Similarly to Falasca \& al. $(2012 ; 2018)$ an agroclimatic zoning model was developed on the basis of the WorldClim data from the period 1950-2000 (https://www.worldclim.org/). The WorldClim data consist of climate grids with a resolution of $1 \mathrm{~km}^{2}$ with an interval of 30 ". Basic data in determining this similarity were: Annual Mean Temperature, Minimum Temperature of Coldest Month, Temperature Annual Range, Mean Temperature of Coldest Quarter, Annual Precipitation, Precipitation of Coldest Quarter. We present four suitability classes based on the percentages of surface occupied in the native range of the species: Optimal, Very suitable, Suitable and, Unsuitable and we have projected with the GIS system the areas that represent these classes on the Italian territory.

\section{Results}

According to our elaborations, in its native range the Argan tree is found in coastal and intra montane areas. Most localities have an annual mean temperature from 13.5 to 20.2 ${ }^{\circ} \mathrm{C}$ and average rainfall from 127 to $413 \mathrm{~mm}$. The minimum temperatures of the coldest month fluctuate from -2.0 to $9.8^{\circ} \mathrm{C}$. The average temperature of Coldest Quarter ranges from 6.0 to $15.4^{\circ} \mathrm{C}$. The ranges of the 4 classes that have been defined on the basis of the percentiles are shown in Table 1 . These data, obtained directly on the basis of the climatic 


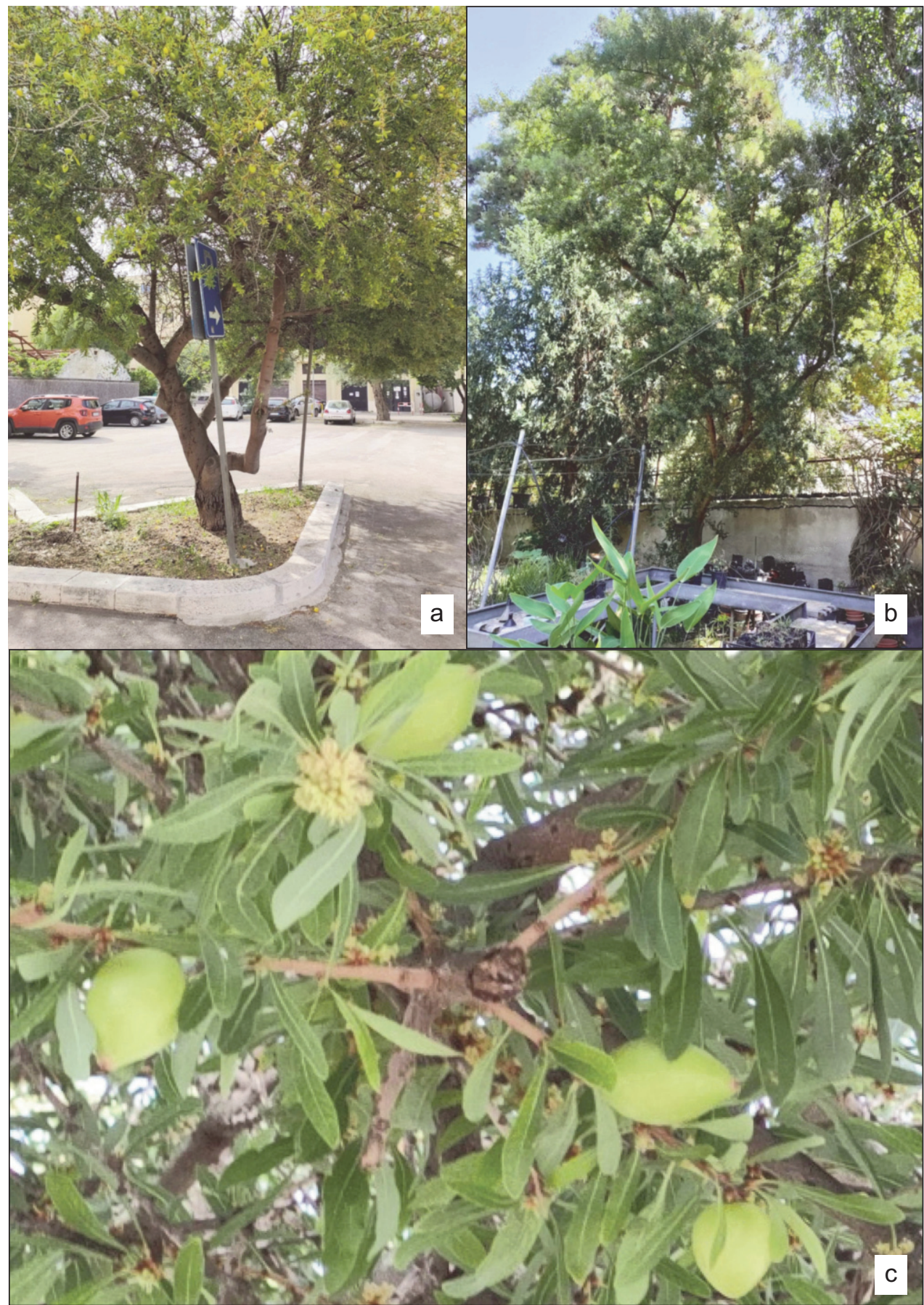

Fig. 1. Argania spinosa: a) in the University Campus of Bari; b) in the Botanical Garden of Bari; c) detail of flowers and fruits. 
Table 1. Climatic parameters of the suitability classes realized.

\begin{tabular}{|l|c|c|c|c|c|c|}
\hline Suitability & Annual Temp. $\left({ }^{\circ} \mathbf{C}\right)$ & $\begin{array}{c}\text { Min. Temp. Coldest } \\
\text { Month }\left({ }^{\circ} \mathbf{C}\right)\end{array}$ & $\begin{array}{c}\text { Mean Temp. Coldest } \\
\text { Quarter }\left({ }^{\circ} \mathbf{C}\right)\end{array}$ & $\begin{array}{c}\text { Max Temp. Warmest } \\
\text { Month }\left({ }^{\circ} \mathbf{C}\right)\end{array}$ & $\begin{array}{c}\text { Annual Rainfall } \\
(\mathbf{m m})\end{array}$ & $\begin{array}{c}\text { Precipitation Coldest } \\
\text { Quarter }(\mathbf{m m})\end{array}$ \\
\hline Optimal & $16.4-18.3$ & $2.8-6.8$ & $10.2-13.2$ & $27.5-31.2$ & $221-307$ & $104-135$ \\
\hline Very suitable & $15.1-16.3,18.4-19.5$ & $-0.1-2.7,6.9-8.2$ & $8.3-10.1,13.3-14.5$ & $24.0-27.4,31.3-33.4$ & $163-220,308-352$ & $79-103,136-144$ \\
\hline Suitable & $9.6-15.0,19.6-23.4$ & $-4.3-0.2,8.3-10.9$ & $2.9-8.2,14.6-15.8$ & $22.9-23.9,33.5-45.1$ & $28-162,353-579$ & $10-78,145-210$ \\
\hline Non suitable & $<9.6,>23.4$ & $<-4.3,>10.9$ & $<2.9,>15.8$ & $<22.9,>45.1$ & $<28,>579$ & $<10,>210$ \\
\hline
\end{tabular}

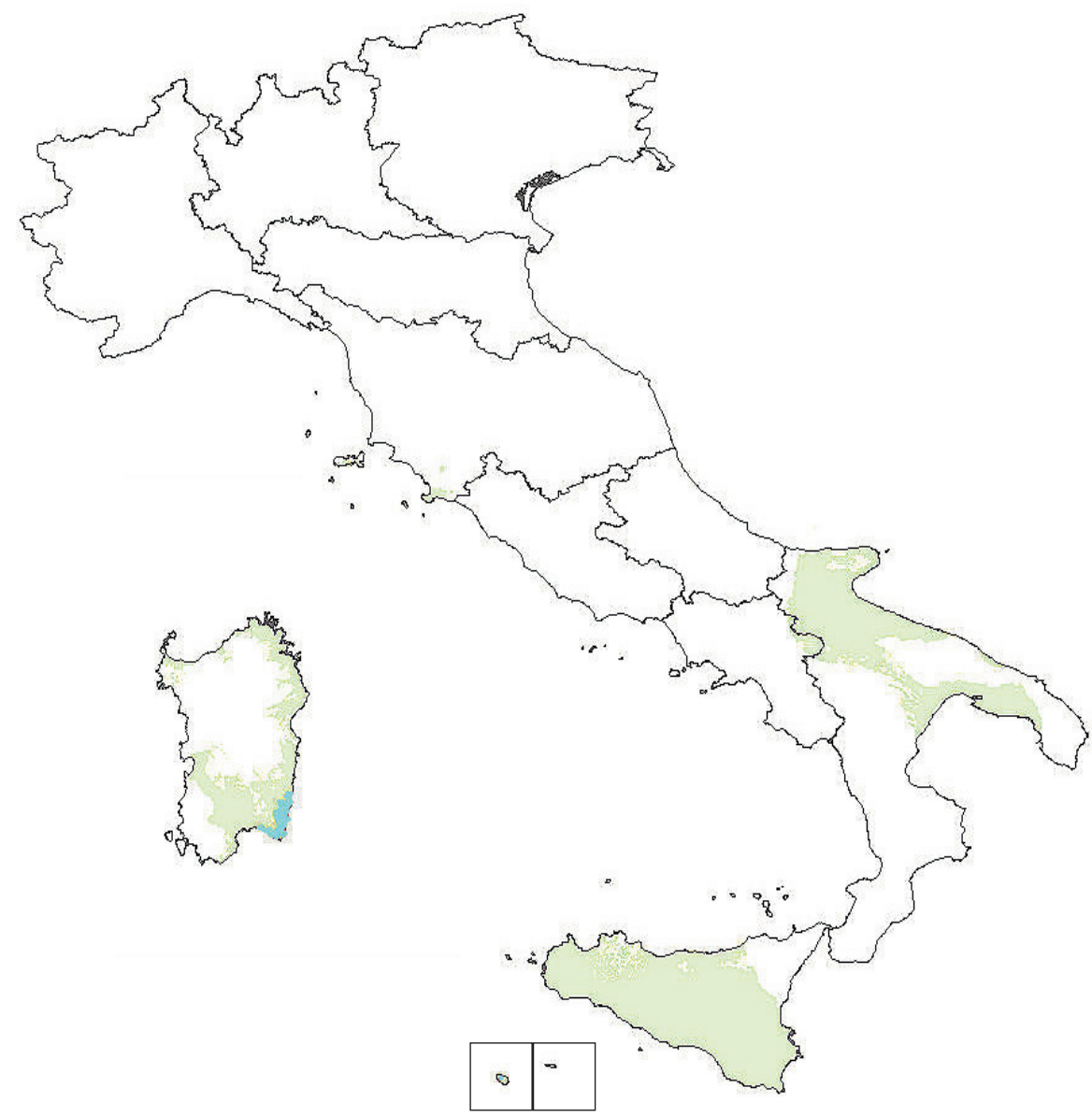

Fig. 2. Areas where the cultivation of Argania spinosa is possible in Italy divided into suitability classes Suitability classes: Very suitable in light blue; Suitable in green. 
indices of the cells in which the plant is present in Morocco, are more accurate than those presented by Falasca \& al. (2018) on the basis of available literature.

It should however be considered that the Argan takes advantage of the occult precipitations derived from oceanic influence which is difficult to quantify.

The successful introduction of this species outside the natural range depends essentially on the degree of similarity of climate in the natural area to that of the new areas with agroclimatic suitability.

Of the four defined suitability classes identified there are no optimal zones for the Argan tree in Italy, and few areas are very suitable for its cultivation in the southeast coast of Sardinia and on the island of Pantelleria. Anyhow, large areas in Sicily, Sardinia and, Apulia are suitable for its use (Fig. 2). The plants grown in Palermo and Bari, which fall into areas classified as suitable, demonstrate the good adaptability of the argan tree in this areas.

\section{Conclusion}

Based on observations carried out on the plants cultivated in Bari and the Botanical Gardens of Cagliari and Palermo, it is possible to consider A. spinosa as a woody species easily adaptable to the coastal climate of southern Italy and other areas in Mediterranean Europe. The presence of leaves on trees throughout the years shows that the character of deciduous plant, in $A$. spinosa, depends on climatic conditions and that the plant, in a cooler and rainy climate, recovers, recovers its possible nature of evergreen species typical of tropical climates.

An experimentation on the territory, based on these forecasting model, can provide further data on the use of this species for urban green, agriculture in marginal areas and reclamation of deteriorated land in south Italy.

The seeds of the argan plant can be find through commercial channels from the Canary Islands however the acclimatization of the A. spinosa plants in southern Italy would provide seeds and material for vegetative reproduction of plants that have already proved to be adapted to the territory for a future use for cultivation and to improve the economy of marginal agricultural areas.

\section{References}

Ait Aabd, N., Bouharroud, R., Tahiri, A., Wifaya, A., Mimouni, A. \& El Mousadik, A. 2019: Genetic Diversity and Breeding of Argan Tree (Argania spinosa L. Skeels). - Pp. 31-56 in: Al-Khayri, J. M., Jain, S. M., Johnson, D. V. (eds) Advances in plant breeding strategies: Nut and beverage crops. - Cham.

Alouani, M. \& Bani-Aameur, F. 2017: Effect of Cold Stress on Nursery Argan (Argania spinosa (L.) Skeels) Seedlings Production. - J. Environ. Sci. Toxicol. Food. Technol. 11(4): 61-66. https://doi.org/10.9790/2402-1104016166

APD 2021: African Plant Database (version 3.4.0). Conservatoire et Jardin botaniques. - Genève. https://www.ville-ge.ch/musinfo/bd/cjb/africa/recherche.php. [Last accessed 10/07/2021].

Campese, E., Tommasi F, Sisto D. \& Mastropasqua L. 2011: Presenza di Argania spinosa (L.) Skeels in Puglia. - Inform. Bot. Ital. 43 (1): 36-37.

Castroviejo, S. 1997: Argania - Pp. 6-8 in: Castroviejo, S., Aedo, C., Laínz, M., Morales, R., Muñoz Garmendia, F., Nieto Feliner, G. \& Paiva J. (eds), Flora Iberica, 5. - Madrid. 
Chakhchar, A., Lamaoui, M., El Kharrassi, Y., Bourhim, T., Filali-Maltouf, A. \& El Modafar, C. 2020: A Review on the Root System of Argania spinosa. - Curr. Agric. Res. J. 8(1): 7-17. https://doi:10.12944/CARJ.8.1.03

Charrouf, Z. \& Guillaume, D. 1999: Ethnoeconomical, ethnomedical, and phytochemical study of Argania spinosa (L.) Skeels. - J. Ethnopharmacol. 67: 7-14. https://doi.org/10.1016/s03788741(98)00228-1

— \& - 2002: Secondary metabolites from Argania spinosa (L.) Skeels. -Phytochem. Rev. 1: 345354. https://doi.org/10.1023/a:1026030100167

Collier, A. \& Lemaire, B. 1974: Etude des caroténoïdes de l'huile d'argan. - Cah. Nutr. Diet. 9: 300301.

Falasca, S. L., Ulberich, C. A. \& Ulberich, E. 2012: Developing an agro-climatic zoning model to determine potential production areas for castor bean (Ricinus communis L.). - Industrial Crops Prod. 40: 185-191. https://doi.org/10.1016/j.indcrop.2012.02.044

Falasca, S. L., Pitta-Alvarez, S. \& Ulberich, A. 2018: The Potential Growing Areas for Argania spinosa (L.) Skeels (Sapotaceae) in Argentinean Drylands. - Int. J. Agron. 2018: 9262659. https://doi.org/10.1155/2018/9262659

Gargano, M. L., Di Gristina, E., Domina, G. \& Venturella, G. 2021: Trees and shrubs in the city of Bari (Italy). - Fl. Medit. 31: 23-30. https://doi.org/10.7320/FlMedit31.023

Guillaume, D., Pioch, D. \& Charrouf, Z. 2019: Argan [Argania spinosa (L.) Skeels] Oil. - Pp- 317352, in: Ramadan M. (ed.) Fruit Oils: Chemistry and Functionality. - Cham. https://doi.org/10.1007/978-3-030-12473-1_16

Justamante, M. S., Ibáñez, S., Villanova, J. \& Pérez-Pérez, J. M. 2017: Vegetative propagation of argan tree (Argania spinosa (L.) Skeels) using in vitro germinated seeds and stem cuttings. Sci. Hortic. 225: 81-87. https://doi.org/10.1016/j.scienta.2017.06.066

Kechairi, R. \& Benmahioul, B. 2019: Comportement des plants d'Arganier (Argania spinosa L. Skeels, Sapotaceae) au sud-ouest Algérien (Tindouf, Bechar et Adrar). - Int. J. Environm. Stud. 76(5): 800-814. https://doi.org/10.1080/00207233.2019.1602378

Khallouki, F., Spiegelhalder, B., Bartsch, H. \& Owen, R.W. 2005: Secondary metabolites of the argan tree (Morocco) may have disease prevention properties. - Afr. J. Biotechnol. 4(5): 381-388.

—, Eddouks, M., Mourad, A., Breuer, A. \& Wyn Owen, R. 2017: Ethnobotanic, Ethnopharmacologic Aspects and New Phytochemical Insights into Moroccan Argan Fruits. - Int. J. Mol. Sci. 18: 2277. https://doi.org/10.3390/ijms18112277

Khayi, S., Gaboun, F., Pirro, S., Tatusova, T., El Mousadik, A., Ghazal, H. \& Mentag, R. 2020: Structural organization and phylogenetic relationships in Sapotaceae. - Plants 9(10): 1354. https://doi.org/10.3390/plants9101354

M’Hirit, O., Benzyane, M., Benchekroun, F., El Yousfi, S. M. \& Bendaanoun, M. 1998: L'arganier: une espèce fruitière-forestière àusages multiples. - Sprimont.

Mechqoq, H., El Yaagoubi, M., El Hamdaoui, A., Momchilova, S., Guedes da Silva Almeida, J. R., Msanda F. \& El Aouad, N. 2021: Ethnobotany, phytochemistry and biological properties of Argan tree (Argania spinosa (L.) Skeels) (Sapotaceae) - A review. - J. Ethnopharmacol. 281: 114528. https://doi.org/10.1016/j.jep.2021.114528.

Médail, F., Monnet, A. C., Pavon, D., Nikolic, T., Dimopoulos, P., Bacchetta, G., Arroyo, J., Barina, Z., Albassatneh, M. C., Domina, G., Fady, B., Matevski, V., Mifsud, S. \& Leriche, A., 2019: What is a tree in the Mediterranean Basin hotspot? A critical analysis. - For. Ecosyst. 6: 17. https://doi.org/10.1186/s40663-019-0170-6

Morton, J. F. \& Voss, G. L. 1987: The argan tree (Argania sideroxylon, Sapotaceae), a desert source of edible oil. - Econ. Bot. 41: 221-233. https://doi.org/10.1007/bf02858970

Moukal, A. 2004: L'arganier, Argania spinosa L. (skeels), usage thérapeutique, cosmétique et alimentaire. - Phytotherapie 2: 135-141. https://doi.org/10.1007/s10298-004-0041-2 
Msanda, F., El Mayad, H. \& Furze. J. M. 2021: Floristic biodiversity, biogeographical significance, and importanceof Morocco's Arganeraie Biosphere Reserve. - Environ Sci. Pollut. Res. https://doi.org/10.1007/s11356-020-11936-0

Nouaim, R., Chaussod, R., El Aboudi, A., Schabel, C. \& Peltier, J. P. 1991: L'arganier: essay synthése des connaissances sur cet arbre. In: Physiologie des Arbres et Arbustes en Zones Arides et Semi-arides. - Paris.

Peltier, J. P., Carlier, G. \& El Aboudi, A. 1990: Evolution journaliere de l'etat hydrique des feuilles d'arganier (Argania spinosa L. Skeels.) sous bioclimat aride a forte infuence oceanique (plaine du Souss, Maroc). - Acta Oecol. 11(5): 643-668.

Raimondo, F. M., Spadaro, V. \& Speciale, M. 2005: Acclimatazione di Argania spinosa (Sapotaceae) nell'Orto botanico di Palermo. - Quad. Bot. Amb. Appl. 16: 83-86.

Tahrouch, S., Hatimi, A., Rapior, S., Mondolot, L., Gargadennec, A. \& Andary, C. 2011: Phenolic compounds of Argan Tree, Argania spinosa (Endemic species of South Western Morocco). Online J. Sci. Technol. 1(4): 17-23.

WCSP 2021: World Checklist of Selected Plant Families. Facilitated by the Royal Botanic Gardens, Kew. - http://wcsp.science.kew.org/ [Last Accessed 15/7/2021]

Yaghmur, A., Aserin, A., Mizrahi, Y., Nerd, A. \& Garti, N. 2001: Evaluation of Argan Oil far DeepFat Frying.- Lebensm. Wiss. Technol. 34: 124-130. https://doi.org/10.1006/fstl.2000.0697

Zunzunegui, M., Ain-Lhout, F., Jáuregui, J., Díaz Barradas, M. C., Boutaleb, S., Álvarez-Cansino, L. \& Esquivias, M. P. 2010: Fruit production under different environmental and management conditions of argan, Argania spinosa (L.). - J. Arid Environ. 74(10): 1138-1145.

Addresses of authors:

Maria Letizia Gargano ${ }^{1}$, G. De Mastro ${ }^{1}$, F. S. D’Amico², Fortunato Cirlincione ${ }^{3 *}$, Emilio Di Gristina ${ }^{3} \&$ Giulio Barone ${ }^{3}$,

${ }^{1}$ Department of Agricultural and Environmental Science, University of Bari Aldo Moro, Via Amendola 165/A, I-70126 Bari, Italy. Emails: marialetizia.gargano@uniba.it, giuseppe.demastro@uniba.it.

${ }^{2}$ Department of Biology, University of Bari “Aldo Moro", Campus Universitario Ernesto Quagliariello, Via E. Orabona, 4, I-70124 Bari, Italy. Email: francescosaverio.damico@uniba.it.

${ }^{3}$ Department of Agricultural, Food and Forest Sciences, University of Palermo, Viale delle Scienze, Bldg. 4, I-90128 Palermo (Italy). Emails: fortunato.cirlincione@unipa.it, emilio.digristina@unipa.it, giuliobarone01@unipa.it *Corresponding author: fortunato.cirlincione@unipa.it 
